\title{
STEAM REFORMING OF SUNFLOWER OIL FOR HYDROGEN GAS PRODUCTION
}

\author{
Dupont, V.
}

Energy and Resources Research Institute, The University of Leeds, LS2 9JT, England

Received: October 10, 2006 Accepted: May 15, 2007

\section{SUMMARY}

Methods of current hydrogen production for the petroleum refinery industry as well as future technologies under research and development in preparation for a global hydrogen-based economy are briefly reviewed. The advantages of biomass and of liquid biofuels, including vegetable oils as fuel sources in the sustainable production of hydrogen gas are then presented. The bulk of this lecture is thereafter concerned with the thermo-chemical means of hydrogen production which are suitable to the conversion of vegetable oil into hydrogen gas. In particular, previous work on the catalytic steam reforming of vegetable oils is summarised and the advantages and drawbacks of conventional steam reforming exposed. The principles behind an exciting novel process of steam reforming called "unmixed steam reforming" (or USR) that is fuelflexible, insensitive to coking, and therefore suitable to unconventional gas and liquid fuels are outlined next. Based on the work carried out at the University of Leeds, preliminary results from tests of the USR process involving sunflower oil fuel are then presented and discussed. To conclude the lecture, future work planned in this area of investigation is outlined.

Key words: sunflower, hydrogen production, liquid biofuels, vegetable oil, catalytic steam reforming

\section{INTRODUCTION}

\section{Hydrogen and the $\mathrm{H}_{2}$ economy}

Energy usage is increasing at a rate many believe to be unsustainable, both from an economic and environmental point of view. The UK consumes an amount of fossil fuels energy equal to approximately 245 million tonnes of oil petroleum annually which provide $88 \%$ of total UK energy consumption.

Petroleum refiners currently operate at levels nearing $90 \%$ of their capacity, leaving them sensitive to even slight variations in global oil supply levels.

Increases in world oil consumption are predicted to rise from 82 to 121 million barrels per day between now and 2030 . 
UK aims to reduce emissions of six greenhouse gases in the years 2008-2012 to $12.5 \%$ below their 1990 level, and finally reduce $\mathrm{CO}_{2}$ emissions by $60 \%$ by 2050 in order to curb the greenhouse effect. To reach this target, various renewable clean energy technologies are developed and hydrogen energy is one of the promising candidates.

The hydrogen economy is not a new idea. The need for hydrogen economy developments is therefore of significant importance at present. Several important factors are widely regarded as being necessary in guaranteeing the successful implementation of a hydrogen economy. The hydrogen must be cost competitive with current energy produced from non-renewable sources and should be of a clean origin if the full benefits of a hydrogen economy are to be exploited. The ultimate conversion of energy present in the hydrogen into usable power must be done so with a high efficiency, sufficient enough to warrant its use over that of current energy technologies.

The matter in universe consists of $75 \%$ hydrogen. It is the lightest and most abundant element on earth. It is only found in nature as bound-hydrogen because of its high reactivity. The most common hydrogen-containing compound is water. Hydrogen has long been considered the cleanest fuel because its only combustion product is water, without toxic emissions or greenhouse gases, unlike carbon containing fuels. Because it is not found as hydrogen gas in nature, hydrogen is not an energy source, but is termed an energy carrier, that is it provides the means for transferring energy. Natural gas and crude oil are energy sources, petrol and diesel are carriers.

Hydrogen is the densest energy carrier in the universe: $1 \mathrm{~kg}$ of it can carry roughly the same energy as $3 \mathrm{~kg}$ of petrol. When combusted, it produces three times as much energy as the same mass of natural gas and six times that of coal. Liquid hydrogen, with its large mass to energy ratio makes excellent rocket fuel. Unlike electricity, hydrogen is easily stored in large amounts as a gas or a (costlier) super cold liquid. Hydrogen gas requires four times the concentration of gasoline fumes to ignite. The flames produced by the combustion of hydrogen only release heat and water, and no pollutants such as smoke, soot, nitrogen oxides or sulphur oxides.

Although internal combustion engines can be modified rather easily to burn hydrogen (with test results displaying efficiency increases of up to $25 \%$ greater than that of gasoline internal combustion engines), its most appealing factor lies in its compatibility with fuel cells. Fuel cells represent decentralized power - they make electricity at the point of use, rather than importing it from distant generators via transformers and long high-tension lines, where significant losses in transmission occur. There are many types of fuel cells, some of them designed to run on other fuels than hydrogen (methanol, natural gas). The transportation industry has adopted the lower temperature and fast start-up characteristics of the Polymer Electrolyte Membrane (PEM) fuel cell (also termed 'Proton Exchange Membrane'). The PEMFC with its high power density, temperature tolerances and fast load 
response is the ideal, environmentally friendly, replacement for internal combustion engines. However, PEM fuel cells suffer the major drawback of extreme electrode sensitivity to even slight concentrations of carbon monoxide.

Iceland has an official goal intent on replacing all oil-reliant transportation, including its ship fleets, with hydrogen by the year 2050. The total cost of conversion to a hydrogen economy in Iceland would be approximately 5 billion Euros (approximately $\$ 7$ billion) (Maack et al., 2006). An estimated $\$ 200$ to $\$ 500$ billion would be required to provide a hydrogen economy capable of equalling current grid capacity in America (Mazza et al., 2004). California's state governor signed an executive order in April 2004 aiming to build a 'hydrogen highway' by 2010. California claims $20 \%$ of car purchases in the US. At present, most developed countries which are dependent on foreign fossil fuel imports have a program of research into realising a hydrogen economy using indigenous fuels and renewable or sustainable sources of energy. This is no doubt being catalysed by the approaching point in time when the demand for oil exceeds its production.

\section{Hydrogen safety}

At room temperature hydrogen is a colourless, non-toxic gas. Hydrogen gas is very light, its density is only 6.9 percent that of air. As a result hydrogen is four times as diffusive as natural gas, and 12 times as diffusive as gasoline. Therefore a hydrogen leak rapidly dissipates as it rises from its source, reducing the risk of fire or explosion. Due to its non-toxicity, a hydrogen leak would not cause environmental damage.

In a confined space, hydrogen could lead to fire or explosion if mixed with air. Any fire started would burn out quickly as the hydrogen dissipated. It is difficult to make a hydrogen-air mix explode - a transient spark can set it off - but it will burn rather than explode, in open air. Some studies have suggested that hydrogen vehicles would have lower risks than petrol vehicles in confined spaces as petrol leaks would create a larger cloud of flammable gas. Hydrogen blazes with little radiation of heat, so nothing would burn unless it was immediately next to the flame. Another safety advantage is that its clear flame cannot sear skin at a distance because of the little thermal radiation emitted by the flame due its lack of soot content. In addition to this, hydrogen storage tanks are much tougher than petrol tanks, and are less likely to cause a big leak.

\section{Global hydrogen production and uses}

Global hydrogen production is currently rated at approximately $5 \times 10^{11} \mathrm{Nm}^{3}$ (500 billion cubic metres) or 44.5 megatons per annum, representing around $2 \%$ of primary energy demand (Ewan et al., 2005). The US Department of Energy (2003) estimates that by 2040 the world would require the annual production of approximately 150 megatons of hydrogen in fuel cell powered cars and light trucks. 
Conventional hydrogen production methods are typically steam reforming, gasification and partial oxidation, implementing the use of fossil fuels, most notably natural gas.

Table 1 represents the feedstock sources of global hydrogen production, clearly illustrating the dominance of natural gas based technologies.

Table 1: 1994 hydrogen production feedstocks (Palm et al., 1999)

\begin{tabular}{lccc}
\hline Source & Billions of $\mathrm{Nm}^{3} /$ year & Millions of metric tons /year & \% total production \\
\hline Natural gas & 240 & 21.6 & 48 \\
Oil & 150 & 13.5 & 30 \\
Coal & 90 & 8.1 & 18 \\
Electrolysis & 20 & 1.8 & 4 \\
TOTAL & 500 & 45.0 & 100 \\
\hline
\end{tabular}

The reason for the current market dominance occupied by this reaction is due to the low cost and relatively high hydrogen conversion efficiencies observed, typically $70-80 \%$ on a dry basis (Ersoz et al., 2006).

According to long-term projections, renewable sources such as biomass, wind and solar energy are suggested to replace natural gas in hydrogen production industry.

Currently the cost of hydrogen is more than twice as much as that of diesel and petrol.

\section{CURRENT HYDROGEN USES}

Current uses of hydrogen are listed below:

- ammonia synthesis and other nitrogenated fertilisers synthesis,

- refining and desulphurisation (hydrogenation reactions, hydrodesulphurisation),

- hydrogenation of hazardous wastes (dioxins, PCBs),

- chemical plants, food preparation,

- synthesis of methanol, ethanol, dimethyl ether (DME),

- alternative fuels synthesis by Fischer-Tropsch synthesis,

- gas to liquid (GTL) synthesis technology,

- rocket fuel,

- internal combustion engine fuel,

- high temperature industrial furnaces fuel.

The International Energy Agency has estimated the worldwide hydrogen consumption around 500 billion $\mathrm{Nm}^{3}$ /year which are shared out amongst the activities listed in Table 2.

The current $\$ 60$ billion world hydrogen business breaks down by usage in the following way:

- $60 \%$ production of ammonia fertiliser 
- $24 \%$ refining and desulfurisation of oil

- $8 \%$ production of methanol

- $8 \%$ industrial uses, such as the hydrogenation of food

The European requirement of hydrogen needed to produce ammonia is 30 billions $\mathrm{Nm}^{3}$ /year, that is to say, 2.7 millions tonnes/year.

Table 2: World hydrogen consumption by different uses

\begin{tabular}{lcc}
\hline Hydrogen Uses & Consumption (billions of $\mathrm{Nm}^{3} /$ year) & Percentage \\
\hline Ammonia production & 250 & 50 \\
Production of other chemical products & 65 & 13 \\
Petrochemistry & 185 & 37 \\
TOTAL & 500 & 100 \\
\hline
\end{tabular}

As far as other chemical products such as methanol, amines or oxygenate water are concerned the industry requirements are significantly lower than those for ammonia production. They are estimated around 15 billions $\mathrm{Nm}^{3} / \mathrm{year}$ that is to say 1.35 millions tonnes/year. (European data collected in 2004).

In Europe, the petrochemical industry's requirement of hydrogen is estimated around 20 billions of $\mathrm{Nm}^{3}$ /year or 1.8 millions tonnes/year.

Table 3: European hydrogen production

\begin{tabular}{lccr}
\hline European $\mathrm{H}_{2}$ production & $\begin{array}{c}\text { Consumption } \\
\text { (billions of Nm} 3 / \text { year) }\end{array}$ & $\begin{array}{c}\text { Consumption } \\
\text { (millions of tonnes) }\end{array}$ & $\%$ \\
\hline Ammonia production & 30 & 2.7 & 46 \\
Production of other chemical products & 15 & 1.35 & 23 \\
Petrochemistry & 20 & 1.8 & 31 \\
TOTAL & 65 & 5.85 & 100 \\
\hline
\end{tabular}

\section{CURRENT HYDROGEN PRODUCTION METHODS}

These are in order of decreasing contribution to world production of hydrogen: steam methane reforming (SMR), coal gasification, electrolysis.

\section{Electrolysis}

Hydrogen produced via electrolysis can result in zero or near-zero greenhouse gas emissions, depending on the source of the electricity used (emissions resulting from electricity generation must be considered when evaluating the environmental benefits of electrolytic hydrogen production technologies).

$$
2 \mathrm{H}_{2} \mathrm{O}+\text { energy } \rightarrow 2 \mathrm{H}_{2}+\mathrm{O}_{2}
$$

Water electrolysis is an established method of hydrogen production, its efficiency is typically in the range of $72-82 \%$ (in reality this value is much less due to the relatively low efficiencies that occur during the production of the electricity consumed in the electrolyser). However, this method of hydrogen production represents a relatively insignificant $4 \%$ of the 500 billion cubic meters of hydrogen 
produced annually (Mazza et al., 2004), accountable primarily due to the extremely high electricity consumption and hence cost (Norsk Hydro Electrolysers estimate that electricity costs account on average for approximately $2 / 3$ of the total operational expenses).

The type of electrolyte employed is usually the factor responsible in naming the electrolyser, resulting in three main categories:

- alkaline electrolyser; employing the use of a liquid electrolyte, a solution generally containing $25 \%$ potassium hydroxide

- polymer electrolyte membrane electrolysers; a relatively new technology, implementing the use of a proton-conducting ion exchange membrane as an electrolyte that couples as a separating membrane for the electrolysis cell. Also called the reversible fuel cell.

- steam electrolysers; operating at high temperatures, typically between 1000 and $1300 \mathrm{~K}$ (Sherif et al., 2005), employing the use of ceramic ion-conducting electrolytes

Alkaline electrolyser technology is currently most suitable for large scale commercial production of hydrogen. Its efficiency is increasing with the development of new electrolyte materials. Research in increasing the efficiency of the electricity conversion of electrolysers is very much active due to the boost caused by the efforts to realise a hydrogen economy.

The electrolysis of water using electricity derived from renewable sources is an extremely attractive method of commercial hydrogen production (wind, solar and tidal powered electrolysis). The majority of water electrolysis, however, is carried out using electricity generated through the consumption of fossil fuels.

Water splitting reactions may be obtained through the use of photovoltaic (PV) systems, the efficiencies of which vary from those witnessed under laboratory conditions and those observed using "off-the-shelf" models. A realistic efficiency may be assumed to be approximately 15\%, resulting in an overall efficiency of $10.6 \%$ when combining an expected $70 \%$ electrolysis efficiency (Ewan et al., 2005). Photoelectrolysis combines the two steps present in the traditional PV system via the submergence of a semiconductor in an aqueous electrolyte. The generation of hydrogen will occur providing the voltage produced by the system is sufficient enough to split water into hydrogen and oxygen. Technological advances in factors maximising the capture and conversion of solar energy make the possibility of a photovoltaic powered hydrogen economy all the more possible. One such example of these advances is the multi-junction technology that achieves high efficiency conversion through the capture of a wider range of light wavelengths. This is still at the research stage.

\section{Gasification}

The gasification of solid fuels in order to mass produce hydrogen has been under serious consideration for some time now. Both coal and biomass are suitable feedstocks for gasification, and will therefore be discussed. 


\section{Coal gasification}

Coal is particularly advantageous as a feedstock due to its global abundance and the lack of political instability associated with the fuel, a fact particularly evident in its comparison with oil. Coal prices are inherently low and are likely to stay that way for the foreseeable future (referring to Tseng (2005), future coal prices are actually predicted to decrease until the year 2040). The total recoverable coal at present is rated at approximately $200,000 \mathrm{EJ}$ (exajoule; joule $\times 10^{18}$ ), equivalent to a 2,000-year supply at the current coal consumption rate. When coupling gasification with $\mathrm{CO}_{2}$ capture, the production of a gaseous fuel with an extremely low emissions rating is achievable.

The mechanism of the gasification process is relatively simple; upon entrance to the gasifier the coal feedstock is reacted with steam and oxygen under high temperature and pressure, resulting in a product gas composed primarily of $\mathrm{CO}$ and $\mathrm{H}_{2}$.

Air may be substituted for oxygen, although dilution of the synthesis gas (syngas) results due to the high nitrogen content of the air. This, however, must be weighed up against the separation costs associated with the production of oxygen for use in the gasifier (an oxygen plant may consume roughly 10-15\% of the gross power generated).

Gasification may in fact be referred to as incomplete combustion in the presence of steam, the main difference between that and standard combustion being the reducing atmosphere present in coal gasification. Oxygen levels in gasification are typically $1 / 5$ to $1 / 3$ of the theoretical amount required for complete combustion.

The actual product gas composition is dependant on several factors, namely the coal and gasifier type, and also the operating temperature and pressure.

As an example, the typical composition of the product gas exiting the KoppersTotzek gasifier is $29 \% \mathrm{H}_{2}$ and $60 \% \mathrm{CO}$, the less significant constituents such as $\mathrm{CO}_{2}$ accounting for the remainder.

The Texaco gasifier, on the other hand, produces a syngas composed of $34 \%$ hydrogen and $48 \% \mathrm{CO}$.

The method of gasification may be tailored to the type of coal employed in the process, the quality of which varies from region to region. Many strategies that are currently being pursued involve gasification coupled with the water gas shift reaction ( $\mathrm{CO}+\mathrm{H}_{2} \mathrm{O} \Leftrightarrow \mathrm{H}_{2}+\mathrm{CO}_{2}$ ), in order to increase the hydrogen output concentration.

The three main types of gasifier typically employed in the process are;

- fixed bed,

- fluidised bed,

- entrained flow.

Low rank coals are most suitable for usage in fluidised bed combustors, a result of not only their non-caking characteristics, but also their higher reactivity. It 
has been proposed that bituminous coals are most suitable for entrained flow gasifiers, although all coals are competent feedstock's (Modelling and simulation for coal gasification, 2000).

Despite the apparent advantages of using coal for hydrogen generation, the hydrogen to carbon ratio possessed by Natural Gas is inherently greater. Generation costs when using coal as a feedstock are therefore close to double that of NGbased production.

\section{Biomass gasification}

The term 'biomass' typically refers to materials that have taken part in the life cycle, and includes plant and animal waste. Biomass commonly used in Europe includes fuel wood, straw, wood residues and pumping liquors. Trees and grasses grown specifically for energy production, such as willow and elephant grass, are known as energy crops and have been the focus of attention for some time now. Many believe current sources of biomass that are relatively untapped, such as fruit and forestry residues, to have a great deal of potential in the areas local to its production. Current excitement surrounding the use of biomass may be accounted to the widespread belief that the energy source is in fact ' $\mathrm{CO}_{2}$ neutral' i.e. $\mathrm{CO}_{2}$ released during plant combustion is equal to that fixed by the plant during growth. However the $\mathrm{CO}_{2}$-neutrality claims are mitigated by the $\mathrm{CO}_{2}$ emitted through transportation and preparation of the biomass. Life cycle analysis is therefore needed in each case where the claim is made.

The biomass gasification mechanism is much the same as that for coal, gas production primarily being the result of partial oxidation. The production of hydrogen is optimised by steam reforming followed by the water gas shift reaction. The overall reaction is as follows;

Biomass + Heat + Steam $\rightarrow \mathrm{H}_{2}+\mathrm{CO}+\mathrm{CO}_{2}+\mathrm{CH}_{4}+$ light and heavy hydrocarbons + char (8)

The process takes place at temperatures in excess of $1000 \mathrm{~K}$. It is possible to optimise the generation of hydrogen by altering certain process parameters, such as temperature and pressure, as well as the design of the gasifier, as outlined previously. Hydrogen generation through sawdust gasification, for example, is optimal at $700^{\circ} \mathrm{C}$ whilst implementing a $\mathrm{Na}_{2} \mathrm{CO}_{3}$ catalyst. A specification of the gasification process requires biomass moisture content to be less than or equal to $35 \%$ (Ni et al., 2006).

Disadvantages of the process include the unwanted tar and ash formation, the level of which is dependent upon the type of biomass used. Tar formation may be minimised through gasifier design considerations, in addition to the employment of suitable catalysts. Ash is a particular problem due to the associated fouling, deposition, slagging and agglomeration. Solutions to remedy ash formation primarily include fractionation and leaching.

Gasification technology in not just confined to singular feedstock's; biomass may be gasified together with coal, as demonstrated by the Royal Dutch/Shell 
group. The co-gasification of biomass and coal has been carried out in the ratio 25/ 75 by the group on a commercial level.

Although the environmentally-friendly nature of the fuel is apparent, large-scale commercialisation of the related technology is likely to remain unrealised for some time. As a result, biomass will most probably only be used as a niche feedstock in regions remote from ready supplies of coal and natural gas.

\section{Steam methane reforming (SMR)}

The Steam Reforming (SR) mechanism is the production of hydrogen via the catalytic conversion of a hydrocarbon and water. Carbon dioxide is an unfortunate bi-product of the SR reaction. As long as a fuel contains carbon, the outcome of its conversion will inevitably be either solid carbon (non GHG) or carbon dioxide (GHG). Technologies are currently being developed to counteract this problem, such as $\mathrm{CO}_{2}$ sequestration (an expansion on this topic is beyond the scope of the report). Reactions (R1) and (R2) represent the reversible production of hydrogen via the discussed process.

Reforming step:

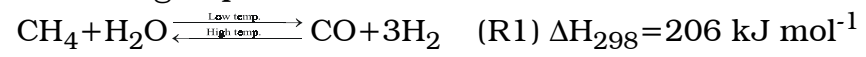

endothermic - needs heating

Water gas shift reaction:

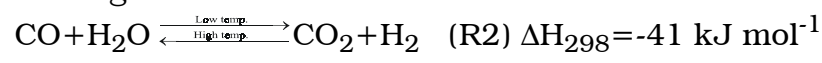

exothermic - releases heat.

The combined reactions are endothermic in nature, resulting in the requirement of an input of heat energy. Commercial SMR processes operate with a high steam/carbon ratio for the production of a hydrogen-rich product stream, additional to the high pressure $(\sim 35 \mathrm{~atm})$ and temperature $\left(850-950^{\circ} \mathrm{C}\right)$ requirements. The elevated steam/carbon ratios such as 3.5 , is chosen to aid in preventing catalyst deactivation through carbon deposition, resulting in the optimisation of catalyst performance (although this is highly temperature dependent) (Ersoz et al., 2006). The high pressure is chosen to increase production rates despite its adverse effects on the thermodynamics of the reaction. The temperature is chosen to avoid carbon formation on the catalyst, but has the unfortunate effect of reversing the water shift reaction and thus decreasing the efficiency of the water conversion into hydrogen. As a result, the product gas leaving the reformer, called the 'reformate' has typically a dry hydrogen content not exceeding $70 \%$, with the remainder a mixture of $\mathrm{CO}$ and $\mathrm{CO}_{2}$. A Nickel catalyst is commonly employed in the reaction, the removal of carbon from the surface of which is aided by the addition of alkali or alkali earths in the catalyst. One or two water shift reactors are then used downstream of the reformer to convert the $\mathrm{CO}$ into $\mathrm{CO}_{2}$, achieving a dry $\mathrm{H}_{2}$ content of typically $75.2 \%$.

The deposition of carbon onto the catalyst occurs via the Boudouard reaction and the decomposition of methane: 


$$
\begin{array}{rlr}
\begin{aligned}
2 \mathrm{CO} \\
\text { exothermic }
\end{aligned} & \Delta \mathrm{CO}_{2} \mathrm{C}=-172 \mathrm{~kJ} / \mathrm{mol} & \text { Boudouard, } \\
\mathrm{CH}_{4} \leftrightarrow \mathrm{C}+2 \mathrm{H}_{2} & \Delta \mathrm{H}^{\mathrm{O}}=+75 \mathrm{~kJ} / \mathrm{mol} & \text { Methane thermal decomposition, } \\
\text { endothermic } & &
\end{array}
$$

The water gas shift reaction is optimal at reduced temperatures, ranging from $200^{\circ} \mathrm{C}$ to $475^{\circ} \mathrm{C}$. Advances in steam reforming conditions, such as increased reforming temperatures and decreased steam to carbon ratios, allow for the optimisation of the energy consumed during the process. A diagram of the steam reforming of methane is presented in Figure 1.

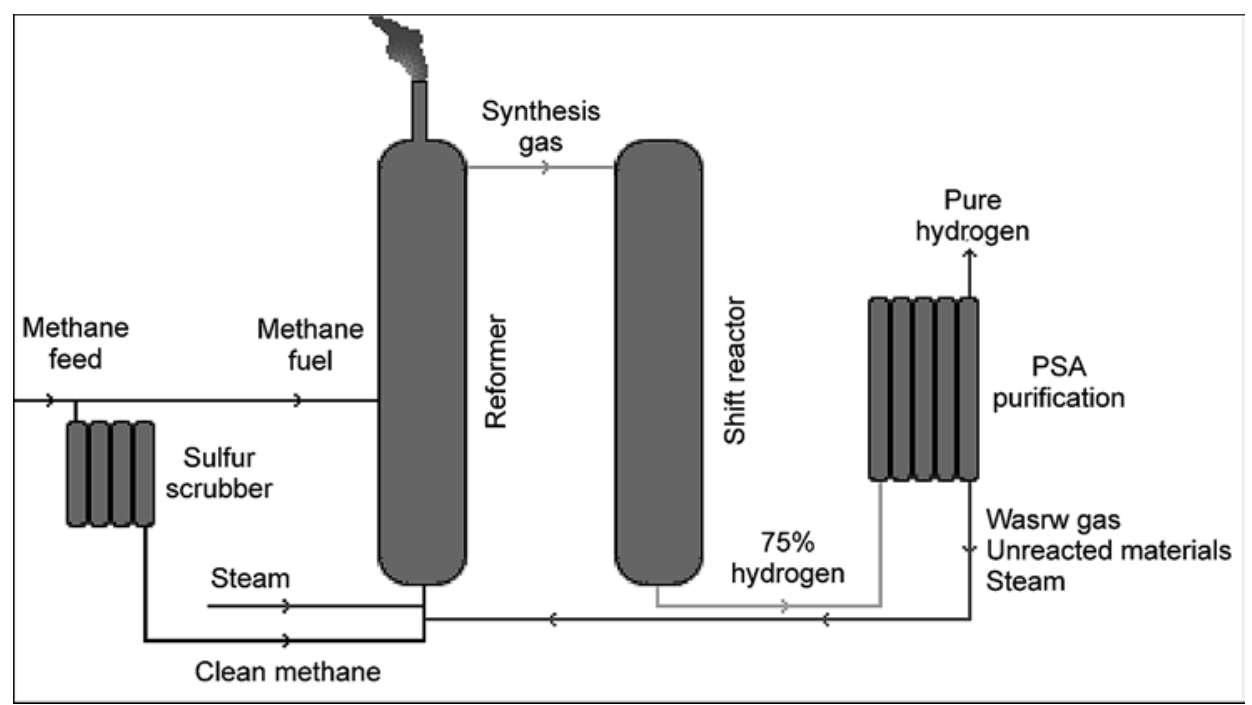

Figure 1: Methane steam reforming illustration. $P S A=$ pressure swing adsorber (removes $\mathrm{CO}_{2}$ from the reformate and produces a pure $\mathrm{H}_{2}$ stream).

Several difficulties encountered in the traditional steam reforming process include diffusion and thermodynamic limitations, and catalyst deactivation due to carbon formation at elevated temperatures. Carbon formation is a complex issue, it occurs readily on acidic Ni-catalysts (temperatures $400-600^{\circ} \mathrm{C}$ ), is removed above that through various reactions (reverse Boudouard, reaction with steam), but is formed in graphitic form again non-catalytically at higher temperature still. If the reactor presents hot spots due to non uniform external heating, such a stable carbon could form there and obstruct the flow. Due to heat transfer issues and inherent heat losses, the process is only valid from an efficiency standpoint at large scale.

In order to achieve the high purity hydrogen gas needed to run an alkaline or PEM fuel cell, or be used as chemical feedstock, the reformate undergoes at least one additional water shift in a separate reactor (but typically two: one at low temperature followed by another at higher temperature), which maximises the conversion of $\mathrm{CO}$ into $\mathrm{CO}_{2}$ while producing hydrogen. The resulting $\mathrm{CO}_{2} / \mathrm{H}_{2}$ mixture is 
finally purified of its $\mathrm{CO}_{2}$ in a Pressure Swing Adsorber, a complex reactor that requires large scale throughput to justify its expense. Overall this is why the current commercial SMR process needs to run at refinery-scale to be economic.

\section{FUTURE HYDROGEN PRODUCTION TECHNOLOGIES}

These include partial oxidation (short contact time reactors), biological production, photochemical production, photoelectrochemical production, thermochemical water splitting, thermal decomposition of methane, and variations of the current thermochemical methods applied to alternative fuels, or modified through the use of mass transfer materials undergoing thermodynamic cycles, such as unmixed steam reforming process.

This paper will concentrate on the latter three methods due to their relevance to the work carried out at Leeds on the unmixed steam reforming of vegetable oil.

\section{Thermal decomposition of methane}

The thermal decomposition of Natural Gas is a hydrogen production method currently under intense investigation. Possible $\mathrm{CO}_{2}$-free generation coupled with the production of a marketable carbon by-product outline the potential of the process. Provided necessary temperatures are obtainable, the decomposition of methane into its constituents is possible. The following reaction may be presented in order to summarise the process;

$$
\mathrm{CH}_{4} \rightarrow \mathrm{C}+2 \mathrm{H}_{2} \quad \Delta \mathrm{H}=74.5 \mathrm{~kJ} / \mathrm{mol} \mathrm{CH}_{4} \text { endothermic }
$$

The endothermic nature of the reaction means that a heat input is necessary. The production of hydrogen is significantly lower than that obtained via the steam reforming mechanism. In SMR, 4 moles of hydrogen are produced per mole $\mathrm{CH}_{4}$ compared with the 2 moles acquired through the thermal decomposition method. On the other hand, through thermal decomposition of methane, the $\mathrm{H}_{2}$ produced is extremely pure, thus largely resulting in the avoidance of expensive gas clean-up. Its product gas can feed directly a PEM or alkaline fuel cell, or be used as chemical feedstock. The process may be carried out either with or without the presence of a catalyst as outlined below.

\section{Non-catalytic thermal decomposition of methane}

In order to produce desirable hydrogen yields in the absence of a catalyst, temperatures in the range 1500-2000 K must be acquired. This heat input is typically derived from fossil fuel sources, however this serves to counteract the $\mathrm{CO}_{2}$-free potential of the process. The implementation of concentrated solar thermal energy will serve to decrease this problem, as will recent advances in the area of plasma technology.

As demonstrated by Dunker et al. (2006), thermal decomposition without a catalyst proves to have a negative effect on the production of hydrogen. Concentra- 
tions lower than 2.7 vol\% were obtained when carrying out the process at temperatures below $868^{\circ} \mathrm{C}$.

\section{Thermo-catalytic decomposition of methane}

In an attempt to reduce the required operating temperature of the process, several catalysts have been developed, the metallic varieties of which are typically based on transition metals. Significant issues, however, have been raised regarding the lifetime of the catalysts, a result of the rapid deactivation due to the carbon formation. Catalyst deactivation may be expressed as a function of temperature and methane flow, increasing the values of which will serve to produce a negative effect on catalyst activity (Villacampa et al., 2003). Oxidation of the carbon on the surface of the catalyst is necessary in its regeneration, a result of which is the production of $\mathrm{CO}_{2}$.

Despite the fact that carbon catalysts are less active than those based on metals, their implementation results in several advantages. Deactivation of the catalyst occurs much slower in comparison to those based on transition metals. Catalyst regeneration and thus $\mathrm{CO}_{2}$ removal is therefore unnecessary, resulting in a gross simplification of the overall process. Carbon based catalysts typically include carbon blacks, activated carbons and graphite, although investigations involving a wider range of catalysts has been demonstrated.

Although often carried out implementing fixed bed reactors, Dunker at al (2006) demonstrated the suitability of fluidised bed technology for thermal decomposition. The absence of catalyst hot spots, a result of thorough in-bed mixing, is one of the reasons for the observed increase in process efficiency. Employing the use of catalyst in pellet form is advantageous due to the reduction in attrition, agglomeration and reactor clogging.

The apparent potential of the process must be weighed up against the current cost implications of certain of its aspects, specifically the catalyst. Provided the carbon produced by the process is sold at a sufficiently high price, the thermo-catalytic decomposition of methane may well compete at an economical level with steam reforming technologies.

\section{Catalytic steam reforming of vegetable oils}

Bio-oils have been studied as fuel feedstocks for the transport sector, looking at vegetable oils from sunflowers and rapeseed plants, as well as residue oil produced from the pyrolysis of municipal solid waste, wood and other biomasses. The use of bio-oils has advantages over ethanol and methane biofuels. Due to the higher hydrogen and lower oxygen content of oils compared to ethanol, and the much higher energy efficiency of producing bio-oils compared to methane produced by anaerobic digestion. The use of vegetable oils has further advantages in that there is already a production and distribution infrastructure in place. Unlike other methods to produced bio-oils for use in hydrogen production such as gasification or pyrolysis of 
biomass, the steam reforming of vegetable oil does not use fossil fuels. The physical and chemical properties of vegetable oil make it very similar to diesel, and have been used as replacements of diesel in internal combustion engines. A massive effort is currently in action to improve the processes of biodiesel synthesis, of which the supercritical methanol process seems the most promising.

A life-cycle analysis carried out by Marquevich et al. (2002) calculated the global warming potential of selected vegetable oils using the conventional catalytic steam reforming process using external heating, and compared the results to those of natural gas and naphtha. The results are given in Table 2, and clearly show that the production of hydrogen from vegetable oils has up to less than half the global warming impact than that of fossil fuels.

The lower $\mathrm{CO}_{2}$ emissions are mainly due to the fact that there are zero net emissions of $\mathrm{CO}_{2}$ made during the actual steam reforming of the vegetable oil, and any other $\mathrm{CO}_{2}$ emissions are due to the extraction and refinement processes, and the operation of the steam reforming processes.

Table 4: GWP associated with the production of hydrogen by steam reformation of various fuels (Marquevich et al., 2002).

\begin{tabular}{lc}
\hline Fuel & GWP over 100 years period $\left.\mathrm{kg} \mathrm{CO}_{2}-\mathrm{eq} / \mathrm{kg} \mathrm{H}_{2}\right)$ \\
\hline Naphtha & 9.46 \\
Natural gas & 9.71 \\
Rapeseed oil & 6.42 \\
Palm oil & 4.32 \\
Soybean oil & 3.30 \\
\hline
\end{tabular}

A Life Cycle Investigation (LCI) was conducted by Marquevich et al. (2002) was conducted on the same three vegetable oils and compared with the two fossil fuels. As biomass $\mathrm{CO}_{2}$ effectively does not contribute towards global warming, the $\mathrm{CO}_{2}$ emissions are given in terms of fossil fuel derived $\mathrm{CO}_{2}$. With regards to air emissions, rapeseed oil actually reduces the $\mathrm{NO}_{\mathrm{x}}$ and $\mathrm{SO}_{\mathrm{x}}$ atmospheric levels due to its intake during the growth of the plant, and so actually has a beneficial effect in that respect. In terms of the water emissions, the different fuels do not differ greatly other than the high COD values for the vegetable oil, this is due to the eutrophication impact from the growth of the plant (use of fertilisers etc.).

Marquevich et al. (2000) investigated the catalytic steam reforming of sunflower oil. They found that the carbon products of thermal decomposition (thermal cracking) of the sunflower oil at $700^{\circ} \mathrm{C}$ were, in order of decreasing contributions, $\mathrm{C}_{2} \mathrm{H}_{4}$ (ethylene) $39.1 \%, \mathrm{CO} 18.4 \%, \mathrm{CO}_{2} 13.7 \%, \mathrm{CH}_{4} 12.5 \%, \mathrm{C}_{3}+13.8 \%$. At the optimum steam to carbon ratio of 6 , the thermal decomposition of mainly ethylene and to a lower extent methane were then responsible for carbon deposition on the catalyst bed which caused a gradual deactivation (decrease in fuel conversion to gases). During the initial reaction time, all the oil was converted to gases in the upstream section of the bed. As the catalyst began to deactivate, the entire bed was used until the reaction front reached the downstream extremity of the bed. Breakthrough of 
ethylene began at $14 \mathrm{~h}$ of running the reactor, and the oil conversion to gases began to drop (deactivation). The oil conversion to gases dropped from $100 \%$ to $75 \%$ oil in $11 \mathrm{~h}$. Marquevich et al. (2000) then investigated steaming as a method to regenerate the catalyst.

Table 5: LCI results for $\mathrm{H}_{2}$ production from fossil and biomass feedstock for $1 \mathrm{~kg} \mathrm{of} \mathrm{H}_{2}$ production (Marquevich et al., 2002).

\begin{tabular}{lcccccc}
\hline Environmental load & & \multicolumn{2}{c}{ Fossil-fuel feedstock } & \multicolumn{3}{c}{ Biomass feedstock: vegetable oils } \\
\cline { 3 - 7 } resources & & Natural gas & Naptha & Rapeseed oil & Soybean & Palm oil \\
\hline Coal (in ground) & $\mathrm{kg}$ & $3.67 \times 10^{-2}$ & $1.84 \times 10^{-2}$ & $2.51 \times 10^{-1}$ & $7.24 \times 10^{-2}$ & $1.85 \times 10^{-2}$ \\
Natural gas (in ground) & $\mathrm{kg}$ & 2.64 & $6.90 \times 10^{-1}$ & $7.69 \times 10^{-1}$ & $7.04 \times 10^{-1}$ & $5.15 \times 10^{-2}$ \\
Oil (in ground) & $\mathrm{kg}$ & $1.75 \times 10^{-2}$ & 2.47 & $5.68 \times 10^{-3}$ & $2.18 \times 10^{-1}$ & $1.41 \times 10^{-1}$ \\
Total primary energy & $\mathrm{MJ}$ & 118.0 & 136.4 & 41.0 & 42.4 & 29.2 \\
Air emissions & & & & & & \\
$\mathrm{CO}_{2}$, fossil & $\mathrm{kg}$ & 7.58 & 9.40 & 1.94 & 3.14 & 2.61 \\
$\mathrm{CO}$ & $\mathrm{g}$ & 1.71 & 1.04 & 1.07 & 3.98 & 4.09 \\
$\mathrm{HC}$ 's (except $\mathrm{CH}_{4}$ ) & $\mathrm{g}$ & 2.05 & $1.96 \times 10^{-1}$ & $6.04 \times 10^{-1}$ & 10.3 & 5.61 \\
$\mathrm{HC} 1$ & $\mathrm{~g}$ & $1.49 \times 10^{-2}$ & $1.60 \times 10^{-2}$ & $4.62 \times 10^{-2}$ & $4.77 \times 10^{-2}$ & $1.49 \times 10^{-2}$ \\
$\mathrm{CH}_{4}$ & $\mathrm{~g}$ & 86.4 & 2.04 & 6.33 & 5.85 & 69.4 \\
$\mathrm{NO}_{\mathrm{x}}$ & $\mathrm{g}$ & 3.21 & 8.15 & -2.17 & 9.05 & 16.0 \\
$\mathrm{~N}_{2} \mathrm{O}$ & $\mathrm{g}$ & $1.79 \times 10^{-2}$ & $1.38 \times 10^{-2}$ & $1.35 \times 10^{-1}$ & $4.65 \times 10^{-2}$ & $1.42 \times 10^{-2}$ \\
$\mathrm{Particulates}_{\mathrm{SO}}$ & $\mathrm{g}$ & 63.9 & 81.8 & 86.5 & 86.7 & 91.9 \\
$\mathrm{SO}_{\mathrm{x}}$ & $\mathrm{g}$ & $8.14 \times 10^{-1}$ & 2.97 & -5.25 & 11.1 & 13.8 \\
$\mathrm{Water}$ emissions $_{\mathrm{Acids}}$ & & & & & & \\
$\mathrm{COD}$ & $\mathrm{g}$ & $7.50 \times 10^{-4}$ & $3.16 \times 10^{-3}$ & $9.40 \times 10^{-4}$ & $9.40 \times 10^{-4}$ & $4.46 \times 10^{-3}$ \\
Oils & $\mathrm{g}$ & $5.99 \times 10^{-2}$ & $9.76 \times 10^{-2}$ & $1.16 \times 10^{-2}$ & 1.25 & 4.51 \\
\hline
\end{tabular}

Steaming over three hours, i.e., flushing the deactivated reactor bed with steam only, at a temperature of $850^{\circ} \mathrm{C}$, achieved complete regeneration of the catalyst reactor bed and $100 \%$ conversion of the oil was restored.

While the oil conversion was dropping, the dry composition of the reformate remained unchanged with respect to hydrogen (constant at $68 \%$ ), $\mathrm{CO}_{2}(17-20 \%)$, $\mathrm{CO}(15-10 \%), \mathrm{CH}_{4}(5 \%)$ and $\mathrm{C}_{2} \mathrm{H}_{4}(0-6 \%)$.

When fuel conversion to gases was highest, the hydrogen yield was $82 \%$. The hydrogen yield is defined by $100 \times$ the ratio of the actual hydrogen yield to the theoretical yield. The theoretical yield is the amount of hydrogen produced if the reforming and water gas shift reactions converted all carbon in the feedstock to $\mathrm{CO}_{2}$.

Later experiments (Marquevich et al., 2003) on sunflower oil at $575^{\circ} \mathrm{C}$ and different $\mathrm{Ni} / \mathrm{Al}$ catalysts prepared from hydrotalcite materials did not improve on the hydrogen yield but achieved much lower $\mathrm{CO}$ content in the reformate, which was compensated by a higher $\mathrm{CO}_{2}$ thereby achieving a higher $\mathrm{H}_{2}$ yield. 


\section{Unmixed steam reforming: the fuel flexible process producing a $\mathrm{H}_{2}$-rich reformate}

Unmixed Steam Reforming originated out of a new type of combustion termed "unmixed combustion". The unmixed combustion mechanism, first encountered in the literature in Kumar et al. (1999) and Lyon and Cole (2000), may be described as an alternative to fire. Its combination with catalytic steam reforming results in a process termed Unmixed Steam Reforming (USR), implementing the use of an oxygen transfer material or OTM (which also acts as catalyst) and a $\mathrm{CO}_{2}$ sorbent.

The OTM catalyst, typically based on $\mathrm{Ni}, \mathrm{Fe}$ or $\mathrm{Cu}$, is employed here primarily to promote oxygen mass transfer, but its catalytic properties have been shown by Dupont et al. (2006) to be equally important in establishing a high steam reforming efficiency. Nickel is often selected due to its high performance, in particular under the high temperature reaction conditions. In the earlier versions of the USR process, the catalyst resides on an inert support material and is housed within a fixed bed reactor, always operating in a transient regime under alternated feed flows of air and vapourised fuel/steam mixture.

The USR mechanism is operated on a two-step cycle, during which the air and fuel-steam flows do not meet throughout the duration of the operation. This is the foundation upon which the technology is based, allowing the technique to be dubbed 'unmixed'. USR may be described as an expansion of the steam reforming $\mathrm{H}_{2}$ production method, accompanied by additional advantages over the traditional technology.

The two flows present in the process may be termed airflow (AF) and fuel/steam flow (FF). The purpose of the AF is twofold; its passage over the Nickel-Oxygen Transfer Material (Ni-OTM) catalyst results primarily in the formation of $\mathrm{NiO}$ via the oxidation mechanism. This reaction (R3), is reversible and may be defined simply as the transfer of oxygen to the Ni catalyst. The heat liberated, a result of the exothermic nature of the reaction, serves to heat up the reactor bed and regenerate the $\mathrm{CO}_{2}$ sorbent $\left(\mathrm{CaCO}_{3}\right)$ to $\mathrm{CaO}$ through its thermal decomposition and resulting loss of $\mathrm{CO}_{2}$. This is illustrated in reaction (R4). Therefore the resultant first-cycle product stream is an $\mathrm{O}_{2}$-depleted, $\mathrm{CO}_{2}$-rich and $\mathrm{N}_{2}$-rich flow. The temperature of the reactor is dependant upon the extent to which the $\mathrm{CO}_{2}$ adsorbent is regenerated.

During FF, the reduction of the Ni-OTM catalyst is initiated through its reaction with the fuel, resulting in the donation of its oxygen. This process is essentially the regeneration of the $\mathrm{Ni}-\mathrm{OTM}$ catalyst. Upon contact between the fuel, steam and the reactor, $\mathrm{CO}$, un-reacted $\mathrm{CH}_{4}$ and $\mathrm{CO}_{2}$ are formed in addition to the $\mathrm{H}_{2}(\mathrm{R} 1)$. The carbonation of the $\mathrm{CO}_{2}$ sorbent (illustrated in reaction (R8)) occurs in unison with the catalyst reduction (R10). This initiates a shift in the equilibrium of the water gas shift reaction to the RHS, resulting in an increase in $\mathrm{H}_{2}$ production and enrichment of the reformate in hydrogen content. The product stream of the FF cycle is extremely $\mathrm{H}_{2}$-rich; levels may be in excess of $80 \%$ dependant upon the fuel 
employed. The temperature of the reactor during the $\mathrm{FF}$ varies according to the reactor pressure and the extent to which the $\mathrm{CO}_{2}$ is adsorbed. It is evident, therefore, that there will be a certain degree of temperature fluctuation between the two cycles.

The reactions that take place in the two cycles are presented below:

First half of the cycle - Airflow (AF)

\begin{tabular}{|c|c|c|c|}
\hline Catalyst oxidation & $\mathrm{Ni}+0.5 \mathrm{O}_{2} \rightarrow \mathrm{NiO}$ & (R3) & Exothermic $(\Delta \mathrm{H}<0)$ \\
\hline $\mathrm{CO}_{2}$ sorbent regeneration & $\mathrm{CaCO}_{3} \rightarrow \mathrm{CaO}+\mathrm{CO}_{2}$ & (R4) & Endothermic $(\Delta \mathrm{H}>0)$ \\
\hline Charcoal oxidation & $\mathrm{C}(\mathrm{s})+\mathrm{O}_{2} \rightarrow \mathrm{CO} / \mathrm{CO}_{2}$ & (R5) & Exothermic $(\Delta \mathrm{H}<0)$ \\
\hline \multicolumn{4}{|c|}{ Second half of the cycle - Fuel/Steam flow (FF) } \\
\hline $\begin{array}{l}\text { Thermal cracking } \\
\text { for methane, } n=1, m=4, k= \\
\text { for sunflower oil, } n=18, m=\end{array}$ & $\begin{aligned} & \mathrm{CnHmOk} \rightarrow(n-k) \mathrm{C}+\mathrm{m} / 2 \mathrm{H}_{2}+\mathrm{kCO} \\
= & 0 \\
= & 34.4, \mathrm{k}=2.1\end{aligned}$ & (R6) & Endothermic $(\Delta \mathrm{H}>0)$ \\
\hline Carbon oxidation by steam & $\mathrm{C}+\mathrm{H}_{2} \mathrm{O} \rightarrow \mathrm{CO}+\mathrm{H}_{2}$ & (R7) & Endothermic $(\Delta \mathrm{H}>0)$ \\
\hline Water gas shift & $\mathrm{CO}+\mathrm{H}_{2} \mathrm{O} \leftrightarrow \mathrm{H}_{2}+\mathrm{CO}_{2}$ & $(\mathrm{R} 2)$ & Exothermic $(\Delta \mathrm{H}<0)$ \\
\hline Steam reforming & $\left.\mathrm{C}_{n} \mathrm{H}_{m} \mathrm{O}_{\mathrm{k}}+(\mathrm{n}-\mathrm{k}) \mathrm{H}_{2} \mathrm{O} \rightarrow \mathrm{nCO}+(\mathrm{n}+\mathrm{m} / 2-\mathrm{k}) \mathrm{H}_{2}\right)$ & (R1 & Endothermic $(\Delta \mathrm{H}>0)$ \\
\hline $\mathrm{CO}_{2}$ adsorption & $\mathrm{CaO}+\mathrm{CO}_{2} \rightarrow \mathrm{CaCO}_{3}$ & (R8) & Exothermic $(\Delta \mathrm{H}<0)$ \\
\hline Boudouard reaction & $2 \mathrm{CO} \leftrightarrow \mathrm{C}+\mathrm{CO}_{2}$ & (R9) & Exothemic $(\Delta \mathrm{H}<0)$ \\
\hline Regeneration of the catalyst 1 & $\mathrm{NiO}+\mathrm{H}_{2} \rightarrow \mathrm{Ni}+\mathrm{H}_{2} \mathrm{O}$ & (R10) & Exothermic $(\Delta \mathrm{H}<0)$ \\
\hline Regeneration of the catalyst 2 & $\mathrm{NiO}+\mathrm{C} \rightarrow \mathrm{Ni}+\mathrm{CO} / \mathrm{CO}_{2}$ & (R11) & \\
\hline
\end{tabular}

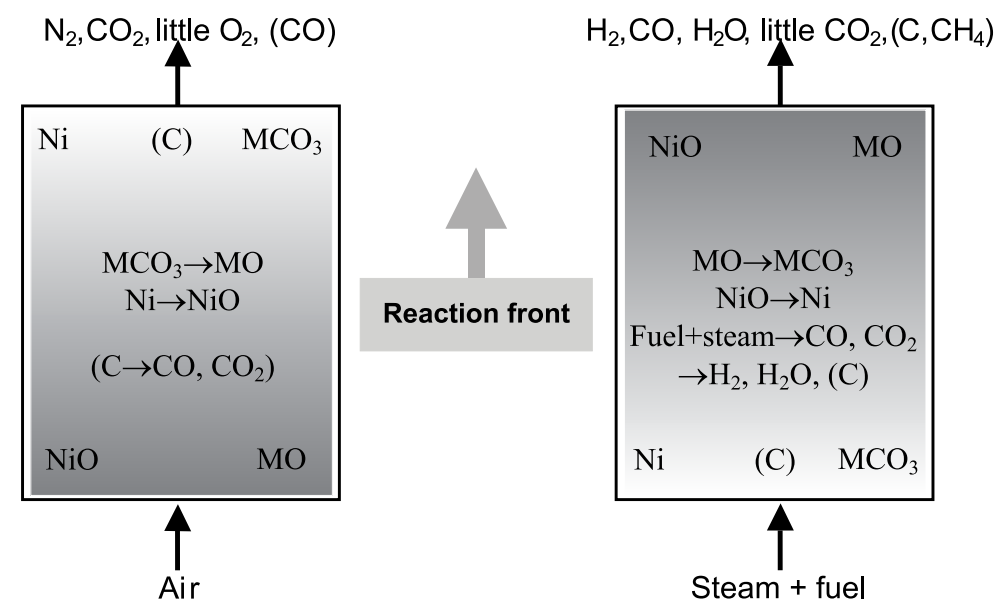

Figure 2: Sequence of the main reactions under the two feed steps.

Many of the problems associated with the traditional steam reforming technologies are solved when employing USR.

The USR has a number of advantages over the other thermochemical methods of $\mathrm{H}_{2}$ production, notably over the conventional catalytic steam reforming process. These are: 
Fuel flexibility. This manifests itself in two ways: coking fuels can be used because if carbon accumulates on the reactant bed during the fuel-steam feed step, it is subsequently burned under the air flow step. The process is therefore insensitive to coking, the major drawback of the conventional catalytic steam reforming process. In addition, Lyon and Cole claimed that the process was insensitive to sulphur poisoning. The oxidation of the liberated sulphur under airflow meant that the irreversible deactivation of the catalyst is negligible. Therefore the fuel constrictions usually associated with steam reforming are less significant when applying USR. Heavier fuels, such as diesel and heavy oils, are therefore suitable for implementation.

No mixing of the streams. The cyclic operation of the process means that there are two separate product streams instead of a single reformate stream. The reformate of the USR process, that is, the product flow under fuel-steam feed is very rich in hydrogen, while the product flow under air feed contains the $\mathrm{CO}_{2}$ from the fuel conversion. Thus purification post-processing of the reformate is much easier as a result. This is relatively unique to USR and certain biological processes such as indirect biophotolysis. A stream consisting of $\mathrm{CO}_{2}$ in the absence of $\mathrm{H}_{2}$ may prove to be beneficial in the future, especially considering the advent of $\mathrm{CO}_{2}$ sequestration technologies or $\mathrm{CO}_{2}$ recycling (such as formic acid synthesis).

Uniform bed heating. The heating of the bed during the AF cycle is even across the cross section, resulting in an absence of hot-spots.

Auto-thermal behaviour; i.e. the reaction should proceed without an input of heat energy; this is possible provided the correct steam, fuel and air streams and feed durations are selected. The catalyst to adsorbent ratio must also be ideal, in addition to the correct choice of time interval between cycles. Steam reforming, on the other hand, is endothermic and therefore requires an input of heat energy in order to proceed. The latter is provided either by external heating via burners, or internally via catalytic partial oxidation. In the former case, combustion emissions and fuel costs are added, in the latter, additional oxidation catalysts sensitivities are to be considered with respect to poisoning and aging.

Lower vessel materials cost. The catalyst bed is the source of the heat during the airflow cycle, meaning that the temperature is greater at the centre of the reactor. The reactor wall material does not therefore need to withstand the oxidation conditions of exposure to flames unlike conventional reformers. Typically the USR reformer could consist of a single stainless steel enclosure, as opposed to the expensive corrosion resistant conventional reformers.

More compact reformer. The reformer can have an aspect ratio closer to 1 given that the heat source is internal. Lyon and Cole (2000) recommend a height to diameter ratio of 1.5. This is in contrast to current reformers which, having to be externally heated, require a long tubular shape several meters long.

Greater $\mathrm{H}_{2}$ yield. This is in comparison with traditional steam reforming. This is a result of the implementation of the $\mathrm{CO}_{2}$ adsorbent combined with regener- 
ation, in addition to the allowance of carbon formation by fuel thermal decomposition. As a comparison, the partial oxidation technologies have inherently poor product quality; typically $40-50 \% \mathrm{H}_{2}$ in the product stream.

Low pressure operation. Operation is typically carried out at 1-2 bar. This provides the process with cost reduction benefits. The economies are realised in lower compressor demands, and higher process efficiency due to more favourable thermodynamics (the steam reforming reaction is more efficient at lower pressures due to its non-equimolarity).

More efficient on a small scale. This results from several effects: (i) the USR process is not bound by the same heat transfer constraints typically associated with traditional steam reforming (conventional SR relies on external heating), (ii) the process does not need to run with the large excess of steam necessary to the conventional process., (iii) the process is efficient at low pressures and low throughputs compared to the conventional process.

In contrast the USR process presents a number of drawbacks:

Intermittent $\boldsymbol{H}_{2}$ production. This is a result of operation in a two-step cycle, where one of the step does not produce hydrogen (the air feed step). Two reactors must therefore be employed out of phase in order to achieve continuous $\mathrm{H}_{2}$ generation.

Possible delayed $\boldsymbol{H}_{2}$ production. Dupont et al. (2006) discovered that the steam reforming reaction is only instigated under the fuel-steam feed step once the Ni-OTM catalyst has been reduced to a sufficient level (typically 10-15\% of its content, but it can be more). With the correct choice of reformer running conditions, this delay can be minimised to half a minute. This means that $\mathrm{H}_{2}$ production can be delayed as a result in conditions of low fuel flow. The problem disappears at high fuel flow due to the contribution of the thermal decomposition of the fuel to hydrogen production at the very onset of the fuel-steam feed step.

Historically the development of the unmixed steam reforming technology followed two strands: the first one preserved the original design criteria of intermittent gas reactant and product flows over a single fixed bed reactor. Methane (Kumar et al., 1999; Lyon and Cole, 2000; Ross et al., 2004; Dupont et al., 2006), diesel (Kumar et al. 1999; Lyon and Cole, 2000) and vegetable oil (Dupont et al., 2006) fuels were investigated with these process specifications.

A second strand attempted to overcome the drawback of intermittent flows by replacing the single fixed bed reactor with three interconnected fluidised beds, with fixed, constant gas flows over each reactor, and circulating materials between each reactor (Rizeq et al., 2003) to allow their various mass transfer steps (sorption/ regeneration). The latter was similar in concept to chemical looping combustion (Ishida, 1987; Son and Kim, 2006) albeit adapted for the steam reforming process. GE Global Research (GEGR) termed the latter technology Unmixed Fuel Processing (UFP) and developed it for pulverised coal-based production of hydrogen intended for fuel cells or combustion turbines and could be integrated into a number of 
advanced power systems. This technology also claimed to offer increased energy efficiency relative to conventional gasification and combustion systems and nearzero pollution. The coverage of the UFP technology here is motivated by the suitability of the UFP process to pulverised fuel such as biomass residue, or mixtures of biomass and coal in pulverised form.

In the UFP technology, three circulating fluidized beds are fed coal, steam and air to produce separate streams of (1) high-purity hydrogen that be utilized in fuel cells or turbines, (2) sequestration-ready $\mathrm{CO}_{2}$, and (3) high temperature and pressure vitiated air to produce electricity in gas turbine (Rizeq et al., 2003). The UFP technology makes use of three circulating fluidized bed reactor containing a $\mathrm{CO}_{2}$ Absorbing Material (CAM) and Oxygen Transfer Material (OTM), just as the original unmixed steam reforming process. The CAM is a sorbent that adsorbs $\mathrm{CO}_{2}$ and the OTM is a metal oxide that oxidises to form OTM-O. Three reactors are connected together and a mixture of the bed material and coal ash is present in each reactor.

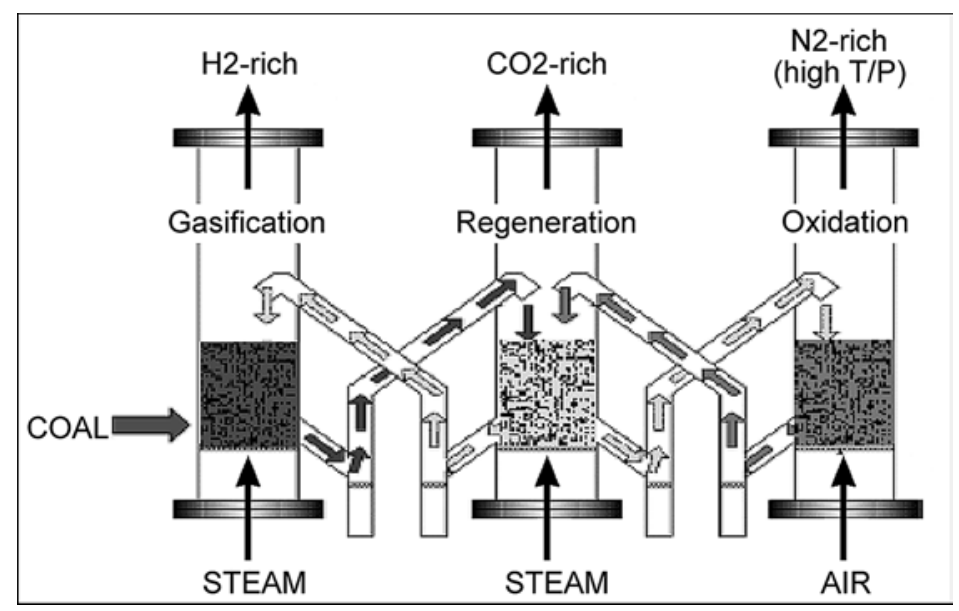

Figure 3: Schematic of operation of the UFP (from Rizeq et al., 2003)

Figure 3 shows how the UFP operates with constant coal and steam feeds to produce a $\mathrm{H}_{2}$-rich gas, a sequestration ready $\mathrm{CO}_{2}$ flow and a hot high pressure exhaust gas $\left(\mathrm{N}_{2}\right.$-rich $\mathrm{O}_{2}$-depleted) which can be used in a gas turbine for added overall process energy efficiency.

\section{Unmixed steam reforming of methane and sunflower oil work at Leeds University}

Figure 4 depicts the experimental set-up for the USR bench scale rig at Leeds University. A close up diagram of the USR reactor can be seen in Figure 5.

Reactant gases were controlled by three mass flow controllers for nitrogen, methane and air followed by three solenoid valves operated in sequence. The liquid feeds of water and vegetable oil were regulated by two actuated valves switching between the AF and FF steps. All valves were centrally controlled by a sequence gen- 
erator. When the unit was not operating (not cycling), a third valve allowed flushing of the assembly with nitrogen.

The product gases were cooled using a water-cooled condenser before entering a water trap (ice bath), followed by a chemical water trap (silica gel). The dry gaseous products $\mathrm{CO} / \mathrm{CO}_{2}, \mathrm{CH}_{4}, \mathrm{H}_{2}$ and $\mathrm{O}_{2}$ were fed through a series of on-line analysers from $\mathrm{ABB}$ and data-logged. The gas reaching the analysers was dry and at room temperature. For safety reasons, the entire gas product stream was diluted with air and $\mathrm{N}_{2}$ and disposed of by flowing it over resistively-heated platinum gauze within an enclosure, where its combustible components were removed by catalytic combustion. Two relief valves were situated before and after the reactor to maintain the reactor pressure below 2 bar. Pressure and temperature readings were measured at various points in the rig as described in Figures 4-5. The reactor had an internal volume of $80 \mathrm{~cm}^{3}$. It contained a combination of an OTM chosen from a previous microreactor study in (Ross et al., 2004) and in the final tests, a mixture of the OTM and a natural dolomite, in ground pellets form of approximately 1-2 mm size, preceded and succeeded by two plugs of alumina particles. We report here experiments where either 80 or $40 \mathrm{~g}$ of OTM were used. The reactor was heated externally by a coiled $1 \mathrm{~kW}$ tubing heater which was actuated in an 'on-off control feedback loop using the middle-reactor thermocouple as the measuring element, and a reference temperature that could be set in the range $600-800^{\circ} \mathrm{C}$. The heating element was first clad with $\mathrm{K}$ wool then surrounded by an alumina casing itself enclosed in a stainless steel casing.

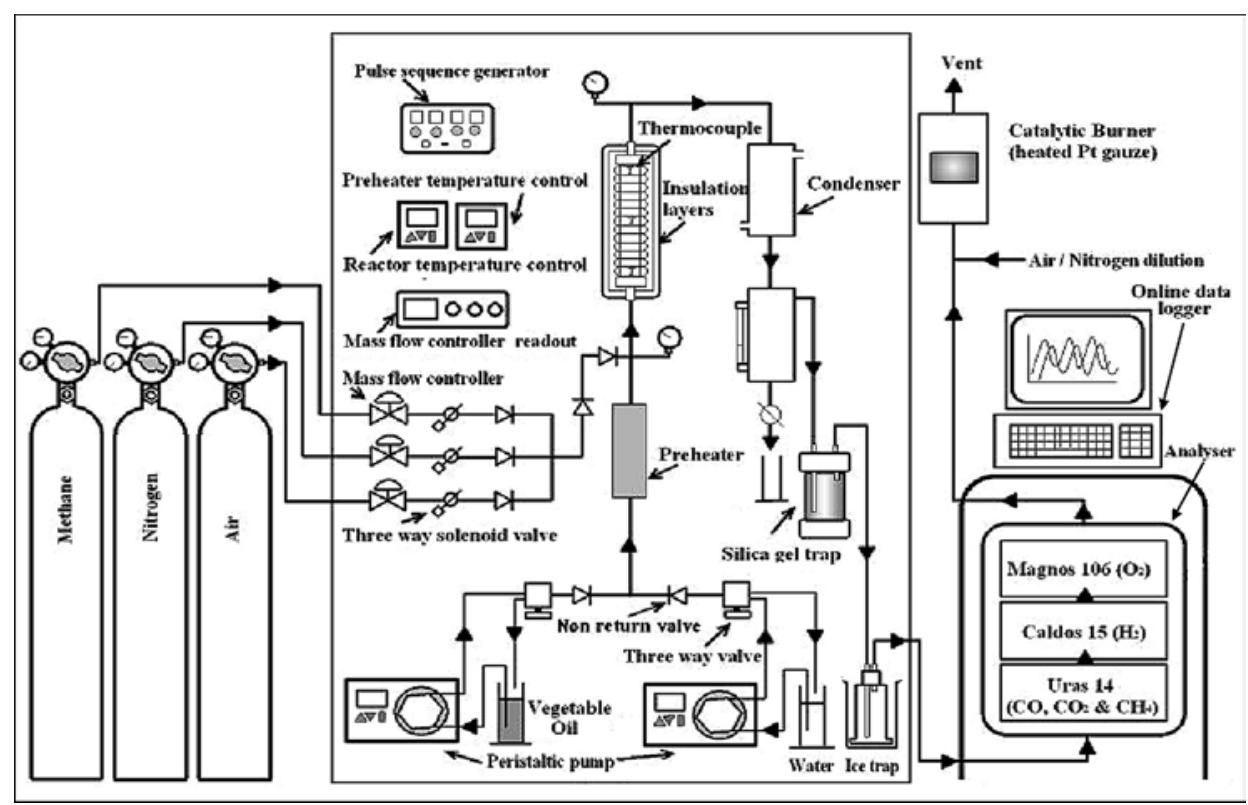

Figure 4: Diagram of bench scale USR set up at Leeds University 


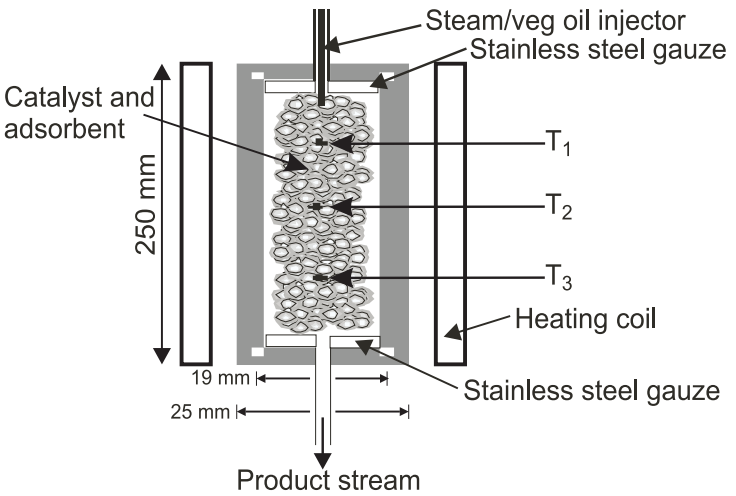

Figure 5: Close up diagram of USR reformer reactor at Leeds University

\section{Methane work}

To understand how the process worked with vegetable oil, a model fuel had to be investigated first with the unmixed steam reforming process. With its simple composition $\mathrm{C}_{1} \mathrm{H}_{4}$, and the relatively few carbon and hydrogen containing products of conversion via thermal decomposition and steam reforming $\left(\mathrm{C}, \mathrm{CO}, \mathrm{CO}_{2}\right)$, methane was the ideal candidate. It presented the added advantage that conventional catalytic steam reforming of methane was well known and therefore provided an excellent basis for comparison to the USR process and the verification of its advantages and drawbacks.
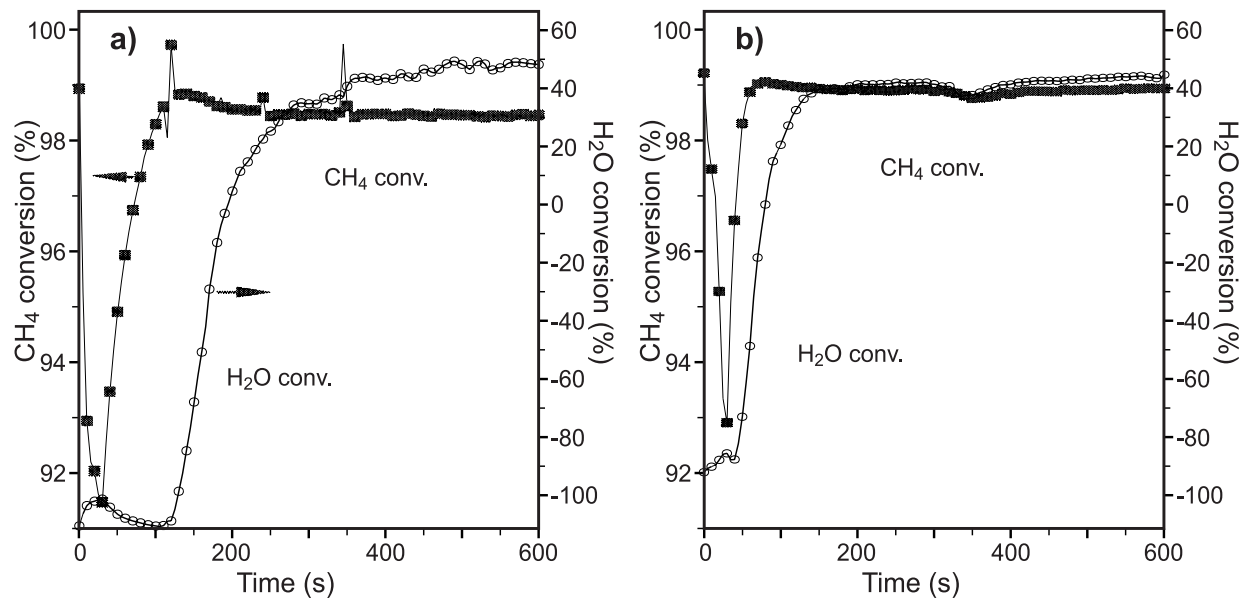

Figures 6a-b: Methane and steam percent conversions during FF (fuel/steam flow step) on $40 \mathrm{~g}$ of OTM 'A' (Ni content of $27.5 \mathrm{wt} \%$ on alumina) for a reactor temperature of $800^{\circ} \mathrm{C}$, at a steam/methane molar ratio of 1.8 using a step duration of $600 \mathrm{~s}(\mathrm{a})$ methane flow of $152 \mathrm{sccm}\left(1.13 \times 10^{-4} \mathrm{~mol}\right.$ of $\left.\mathrm{C} / \mathrm{s}\right)$ and (b) $400 \mathrm{sccm}\left(3 \times 10^{-4} \mathrm{~mol}\right.$ of $\mathrm{C} / \mathrm{s}$ ). These runs were without $\mathrm{CO}_{2}$ sorbent. (Dupont et al., 2006) 
The graphs of Figures $6 a$ and $6 \mathrm{~b}$ indicate that with the USR process, the steam, with a conversion of $42-48 \%$, is as valuable a source of hydrogen as the fuel (98\%). This is unlike the conventional catalytic steam reforming process which operates with a steam to carbon ratio of at least 3.5, i.e. with a large excess of water which carries purification, vapourisation and recycling costs. In many parts of the world the availability of clean water might be an issue, and being able to operate at a steam to carbon ratio of 1.8 as in the USR process could be very advantageous.

Figure $6 \mathrm{~b}$, which represents an operation with a larger fuel/steam inflow (400 sccm or $\mathrm{cm}^{3} / \mathrm{min}$ at STP) than Figure 6 a (152 sccm), indicates that choosing the right flow for the reactor size has large consequences on the time at which steam reforming initiates. Given that the FF duration is short, of the order of 6-10 minutes, this has a crucial role in the overall hydrogen production efficiency, when integrated over the whole fuel-steam step duration.

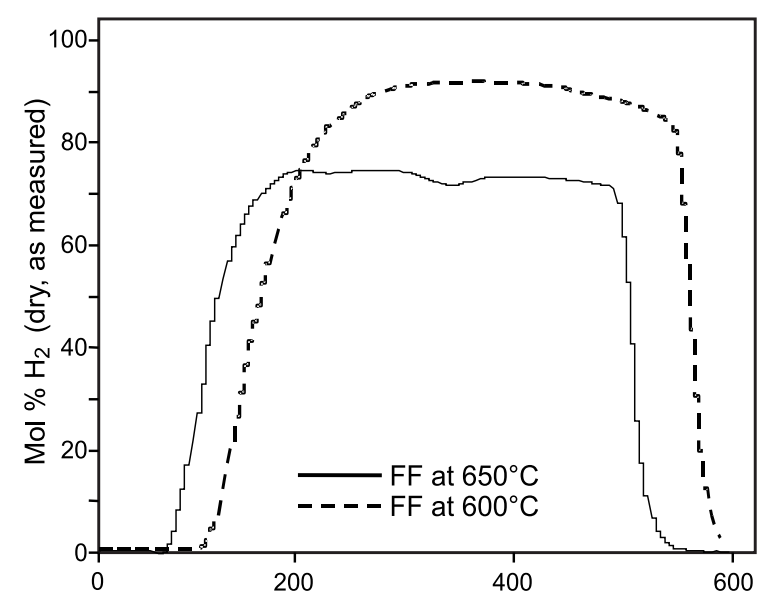

Figure 7: $\mathrm{H}_{2}$ content in reformate (on a dry basis) when using a reactor set temperature of $600^{\circ} \mathrm{C}$ (dashed line) and $650^{\circ} \mathrm{C}$ (solid line) during $\mathrm{FF}$ step, over $64 \mathrm{~g}$ of OTM 'A' and $21 \mathrm{~g}$ of dolomite homogeneously mixed. The flow of methane was maintained at $200 \mathrm{sccm}$, with a steam to carbon ratio of 4 .

The effect of operating with dolomite as the $\mathrm{CO}_{2}$ sorbent in the reactor is illustrated in Figure 7. At a reactor temperature of $600^{\circ} \mathrm{C}$, the purity of the reformate reaches above $90 \%$ in hydrogen. The same experiment with a reactor temperature of $650^{\circ} \mathrm{C}$ lowers the reformate $\mathrm{H}_{2}$ purity to $75 \%$. When a reformate purity of $75-90 \%$ is achieved, downstream water shift reactors are not necessary, which reduces the capital and operating costs of the process.

\section{USR operation with sunflower oil}

Table 6 indicates that the dry $\mathrm{H}_{2}$ content achieved in the reformate in the absence of $\mathrm{CO}_{2}$ sorbent is, with a value of $67.2 \%$ very similar to that obtained previously by Marquevich et al. (2000). However in the Leeds runs, the conversion of 
steam (32\%), thanks to an operation with a steam to carbon ratio of 1.8 , contributes greatly to the overall $\mathrm{H}_{2}$ production efficiency. A drawback is found in this run: for $25 \%$ of the initial fuel/steam step duration, steam reforming is inactive and indicates optimisation of the flows for this reactor load could achieve an earlier activation of the steam reforming reaction, as carried out for the methane experiments.

Table 6: Results obtained for OTM 'A' during the bench scale USR Leeds University tests using sunflower oil with $\mathrm{N}_{2}$-diluted steam/C ratio of 1.8 in the absence of $\mathrm{CO}_{2}$-sorbent over a bed of $80 \mathrm{~g}$ of $\mathrm{OTM}$ at $700^{\circ} \mathrm{C}$. Average values are reported for the period of established steam reforming. The duration of the FF step was $400 \mathrm{~s}$. Sunflower oil molar composition: $\mathrm{C}_{18} \mathrm{H}_{34.4} \mathrm{O}_{2.1}$. (Dupont et al., 2006)

\begin{tabular}{|c|c|c|c|c|c|c|c|c|c|}
\hline \multirow{2}{*}{$\begin{array}{l}\text { *Oil liq. } \\
\text { flow } \\
\mathrm{cm}^{3} / \mathrm{min}\end{array}$} & \multirow{2}{*}{$\begin{array}{c}\begin{array}{c}\text { Oil molar } \\
\text { in flow }\end{array} \\
\text { Mol/s }\end{array}$} & \multirow{2}{*}{$\begin{array}{l}\text { Dead } \\
\text { time }\end{array}$} & \multicolumn{2}{|c|}{ Conv } & \multicolumn{2}{|c|}{$\%$ Carbon products selectivity } & \multirow{2}{*}{$\begin{array}{l}\% \text { corr. } \\
\text { dry } \mathrm{H}_{2} \%\end{array}$} & \multirow{2}{*}{$\stackrel{\mathrm{H}_{2}}{\text { Prod. Eff. }}$} & \multirow{2}{*}{$\begin{array}{l}\text { Final } \\
\mathrm{H}_{2} \mathrm{Eff}\end{array}$} \\
\hline & & & oil & $\mathrm{H}_{2} \mathrm{O}$ & $\mathrm{CO}_{2} \quad \mathrm{CO}$ & n) & & & \\
\hline 0.575 & $3.1 \times 10^{-5}$ & $1 / 4$ & 100 & 32 & $\begin{array}{ll}36.6 & 7.9\end{array}$ & 15.5 & 67.2 & 0.44 & 0.37 \\
\hline
\end{tabular}

Further optimisation could be achieved in converting the methane by-product ( $15 \%$ of carbon products) to hydrogen and $\mathrm{CO}_{2}$, and this can be done by using a higher temperature in the reactor. With regards to other carbon products of the thermal cracking of the sunflower oil (mainly $\mathrm{C}_{2} \mathrm{H}_{4}$ ethylene), it is expected that at the temperature of $700^{\circ} \mathrm{C}$, these would have undergone either catalytic cracking to carbon and hydrogen, or steam reforming as found in early experiments at Leeds (Powell, 2003) and in the work of Marcquevich et al. (2000).

The large carbon deposition resulting from the high carbon selectivity would eventually poison the catalyst, but the advantage of the USR process is that the fuel/ steam steps are of short durations (6-10 min) and followed by the air feed step, during which the carbon burns and the bed material regenerates and heats up.
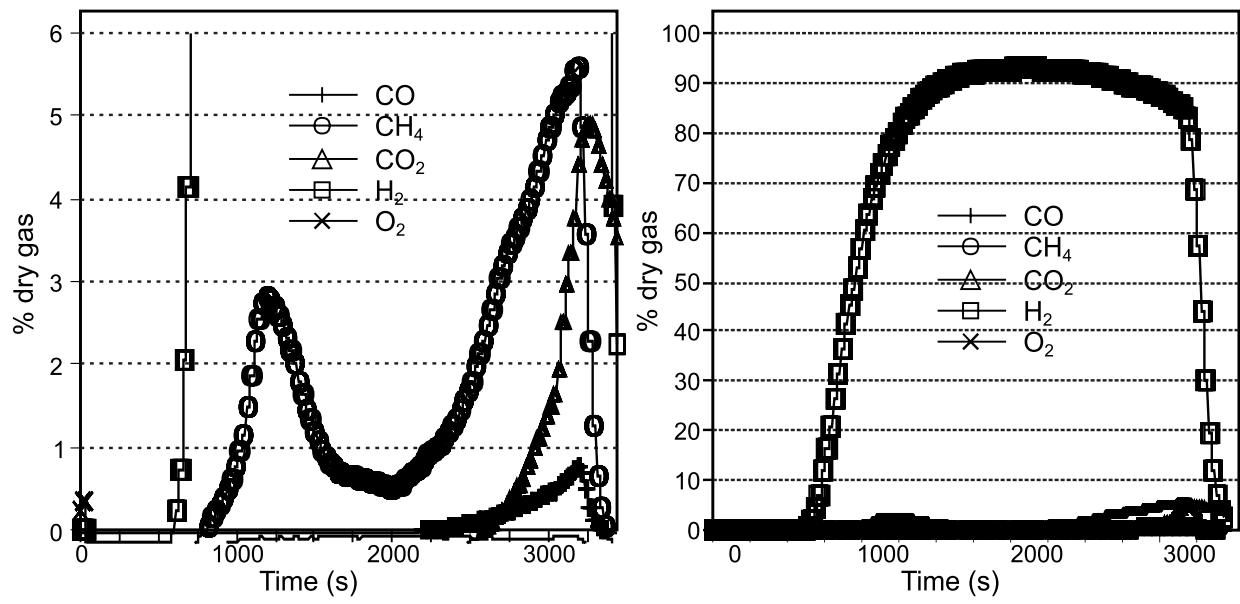

Figures 8a-b: Dry reformate composition for conditions of Table 6 (steam/sunflower oil feed, ratio of 4) this time with dolomite mixed with Ni-OTM 'A' present in the USR reformer reactor. Figure 8a: lower scale emphasises the minor reformate products $\left(\mathrm{CO}, \mathrm{CO}_{2}, \mathrm{CH}_{4}\right.$, $\mathrm{O}_{2}$ ), Figure 8b: larger scale shows the major reformate product hydrogen 
The results shown in Figures 8a-b are from early tests at Leeds University and indicate that it is possible to obtain a reformate with more than $90 \%$ dry $\mathrm{H}_{2}$ content when using sunflower oil to fuel the USR process, when using dolomite as the $\mathrm{CO}_{2}$ sorbent and the Ni-OTM catalyst with a medium-high Nickel content ('A' contains $27.5 \mathrm{wt} \% \mathrm{Ni}$ impregnated on an Alumina support). We found that such an excellent operation is difficult to sustain over repeated cycles when operating with a single set temperature, and attribute the lower dry $\mathrm{H}_{2}$ content of subsequent cycles (shown in Figure 9 ) to the lack of regeneration of the dolomite at the set reactor temperature of $600^{\circ} \mathrm{C}$ during the air flow. This would indicate that during the air flow, this temperature is insufficient to decompose the carbonate, and as a result the $\mathrm{CO}_{2}$ can no longer adsorb with a resulting increase in reformate $\mathrm{CO}_{2}$ content in the following fuel-steam step. One can see from the air feed steps dry gas compositions that some $\mathrm{CO}_{2}$ evolves from the reactor but that this is likely to be due to carbon combustion rather than carbonate decomposition given the large $\mathrm{CO}_{2}$ concentrations found during the subsequent fuel-steam feed step. As an optimisation step, it would be therefore be useful to increase the reactor set temperature to $800^{\circ} \mathrm{C}$ during the air feed steps, to ensure regeneration of the $\mathrm{CO}_{2}$ sorbent.

It is also interesting to note that the second and third cycles produce a similar reformate composition to that of Marquevich et al. (2003), in that hardly any CO is found in the reformate. In contrast, some methane is found, indicating that the process could be further optimised by achieving its decomposition or steam reforming.

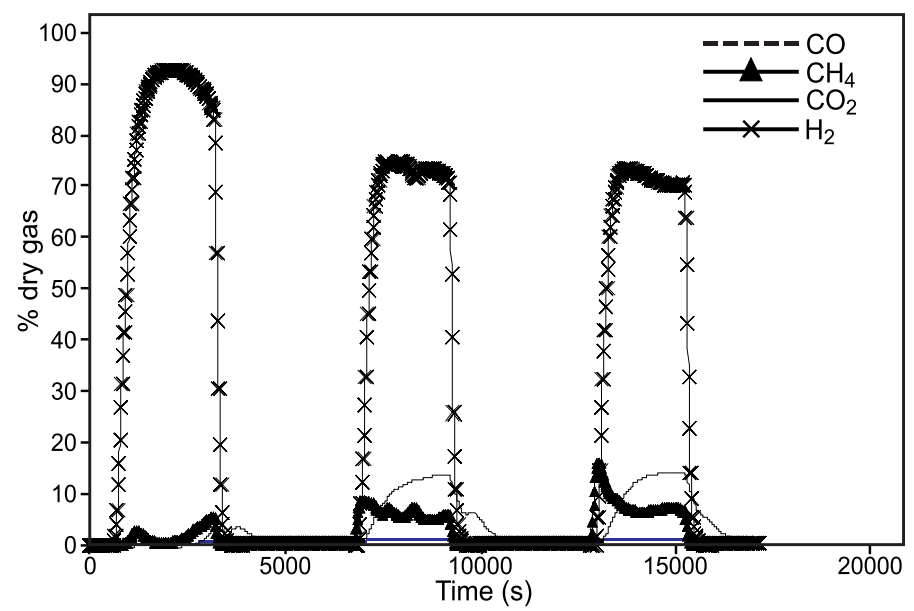

Figure 9: Dry reformate gas composition for three initial cycles sunflower oil+steam feed/ air feed in conditions of Figure 8ab. In order of decreasing content: $\mathrm{H}_{2}>>\mathrm{CO}_{2}>\mathrm{CH}_{4}>>\mathrm{CO}$.

\section{Future work at Leeds}

Significant work is on-going at Leeds to find the optimum conditions for the mechanism of the Ni-OTM reduction. It has been established that the steam reforming reaction is delayed until the Ni-OTM catalyst has been reduced to a certain level 
(minimum of ca. 15\%). Any hydrogen produced up to then is via the less efficient thermal decomposition reaction of the fuel, which does not use the added value of the water-hydrogen content. It is therefore crucial to establish steam reforming as soon as possible given that the Ni material operates equally as an oxygen transfer material and as a steam reforming catalyst. The latter has implications with respect to the sensitivity of the material to poisons and might compromise the claims of fuel flexibility as a result. Another strand of the project is dedicated to the optimisation of the autothermal behaviour, so far very little explored, using methane and sunflower oil as the fuel. In continuation to this, more challenging fuels will be investigated, such as waste cooking oil, pyrolysis oils from pine wood residue, and also myscanthus as representatives of high lignin and low lignin biomass sources respectively, producing highly oxygenated oils. Industrial waste oil and pyrolysis waste tyre oils will also be studied, to represent low oxygen high sulphur content oils. It is also intended to devote another section of the study to the development of appropriate $\mathrm{CO}_{2}$ sorbents for these oils.

\section{Implications for distributed electrical power generation using a pilot plant sunflower fuelled USR}

The sunflower oil-fuelled USR process at pilot scale, with the aims of continuously powering a fuel cell for electricity generation would have to rely on two USR reactors operating out of phase: while one is under fuel-steam feed, the other is under air feed and vice versa, ensuring an uninterrupted supply of hydrogen-rich reformate (see Figure 10).

There are various types of fuel cells, but those which require very pure hydrogen as their fuel (polymer electrolyte membrane fuel cells, alkaline fuel cells) need to be discarded since this would necessitate expensive purification steps downstream of the USR reformers. This leaves the 'molten carbonate', 'phosphoric acid' and 'solid oxide' fuel cells (MCFC, PAFC, SOFC), their names referring to the type of electrolyte they rely on. The first kind (MCFC) tends to be used at very large scale (2 to $100 \mathrm{MW}$ ) due to the complexity of operating with a liquid electrolyte which needs continuous $\mathrm{CO}_{2}$ injection. Their temperature of operation $\left(650^{\circ} \mathrm{C}\right)$ is however well suited to its coupling with a reformer, allowing heat integration and co-generation (steam and electricity generation). Phosphoric acid fuel cells rely on a Pt catalyst at the electrodes to speed up the decomposition of hydrogen and the formation of water, but because they operate between 150 and $200^{\circ} \mathrm{C}$, they have a tolerance to CO content up to $1.5 \%$. They are used for stationary power generation. For instance a 250-kilowatt phosphoric acid fuel cell powers a police station and is used to recharge a police electric vehicle in New York's Central Park. Whereas 1.5\% CO content can be achieved by a well tuned sunflower oil fuelled USR process, fluctuations due to autothermal operation could exceed this value occasionally, leading to gradual poisoning of the PAFC electrodes. 
This leaves the SOFC. The SOFC operates in the $700-1000^{\circ} \mathrm{C}$ range, and is very tolerant of impurities in the reformate. This implies that the heat required by the SOFC could be recycled to the reformer and increase the overall efficiency of the sunflower oil to electricity conversion process. Although SOFCs can run on non- $\mathrm{H}_{2}$ rich reformate, and even natural gas, by extracting the hydrogen at its electrode, the efficiency of the SOFC is improved with $\mathrm{H}_{2}$ content in the fuel and SOFC are often operated downstream of a reformer (see Figure 11).

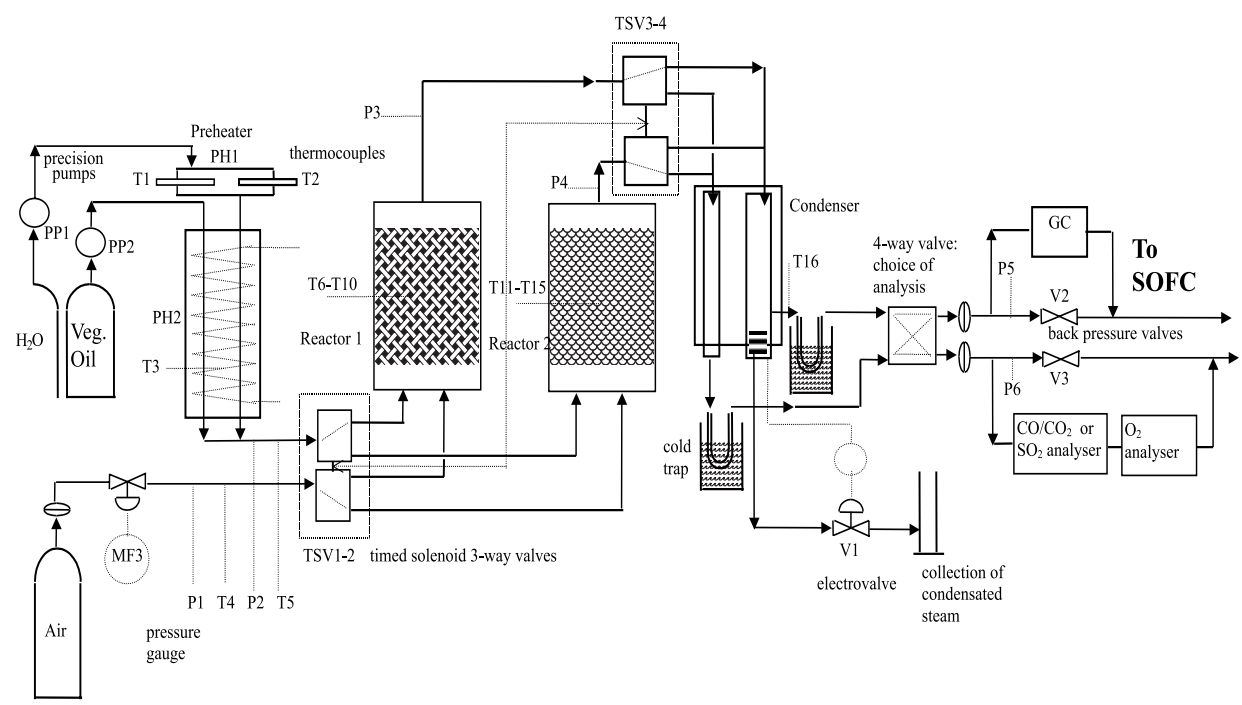

Figure 10: Diagram of pilot scale USR for continuous production of $\mathrm{H}_{2}$ used to feed a SOFC

Typically 30-250 kW SOFC units are sold, and can be combined with microturbines for re-using the steam product. One of the big advantages of the SOFC over the MCFC is that the electrolyte is a solid. This means that no pumps are required to circulate hot electrolyte. Small planar SOFC of $1 \mathrm{kw}$ could be constructed with very thin sheets and result in a very compact package. The Solid State Energy Conversion Alliance (SECA) was created by NETL (the U.S. National Energy Technology Laboratory) to accelerate the development of solid oxide fuel cells (SOFC) and get them to the market as quickly as possible while making them an affordable option for energy generation. The SECA program aims to get SOFCs on the market by 2010 at a cost of $\$ 400 / \mathrm{kW}$, nearly a factor of 10 less than the cost at the program's inception. These fuel cells will be $3-10 \mathrm{~kW}$ in size, adaptable for various applications and ideal for distributed power generation. Prototypes of intermediate temperature fuel cells are being developed through dynamic collaborative research programs in the U.S. for this purpose. 
The SOFCs commercially produced through the SECA programme in the US by 2010 will surely provide the most suitable fuel cell option for coupling with a pilotscale sunflower oil-fuelled USR process due to its power range and fuel flexibility.

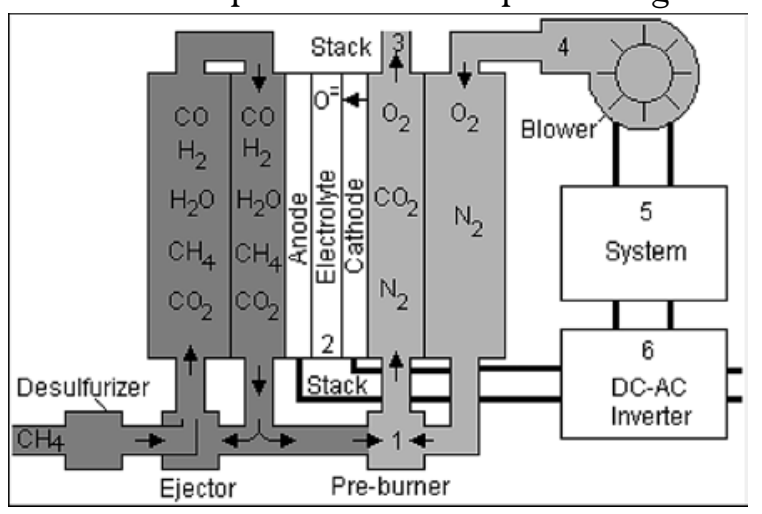

Figure 11: Diagram of operation of a Solid Oxide Fuel Cell fuelled by natural gas. A reformate fuelled SOFC would not need the pre-reformer on the left hand side. (Ben Wiens Energy Science Inc., 2006)

\section{Calculations of sunflower oil flow, reformer size to power a $10 \mathrm{~kW}$ SOFC, cost of $\mathrm{kWh}$}

Assuming a conservative 55\% efficiency for the SOFC (based on the Free Gibbs Energy flowrate conversion into electrical power), in order to obtain $10 \mathrm{KWel}, 18.18$ $\mathrm{kW}$ of Free Gibbs Energy flowrate in the form of hydrogen/oxygen are needed. The Free Gibbs Energy $(\Delta \mathrm{G})$ for the reaction of $\mathrm{H}_{2}$ and $\mathrm{O}_{2}$ recombination into water is $237.13 \mathrm{~kJ} / \mathrm{mol}$ of $\mathrm{H}_{2}$. Therefore approximately $7.67 \times 10^{-2} \mathrm{~mol} \mathrm{of} \mathrm{H}_{2} /$ second would be necessary to feed a $55 \%$ efficient $10 \mathrm{~kW} \mathrm{SOFC}$, and would need to be produced by the two USR reformers in parallel.

According to the Leeds University test reported in Table 6, a liquid flow of $0.575 \mathrm{~cm}^{3} / \mathrm{min}$ of sunflower oil at STP, operated at a steam to carbon ratio of 1.8 , corresponded to $5.33 \times 10^{-4} \mathrm{~mol}$ of $2 \mathrm{H} / \mathrm{s}$ fuelling the reactor. Using a pessimistic overall fuel-steam conversion efficiency of 0.37 (last value in Table 6), this translates as $1.972 \times 10^{-4}$ moles of $\mathrm{H}_{2} / \mathrm{s}$ produced by the two reformers. Therefore in order to achieve a reformate flow of $7.67 \times 10^{-2} \mathrm{~mol}$ of $\mathrm{H}_{2} /$ second, a feed-flow 389 times larger of sunflower oil would be required, that is, $224 \mathrm{~cm}^{3} / \mathrm{min}$ (or $13.44 \mathrm{1} / \mathrm{h}$ of liquid sunflower oil). From an initial reactor of $80 \mathrm{~cm}^{3}$ internal size, the reactors would have to be scaled up by a factor of 389 as well, corresponding to reactor volumes of $31.1 \mathrm{l}$. If these are cylindrical-shaped reactors, with the aspect ratio of 1.5 recommended by Lyon and Cole (2000) for the USR process, then the reformer reactor sizes would be roughly $40 \mathrm{~cm}$ diameter and $60 \mathrm{~cm}$ tall. Heat integration concepts would be implemented to use the steam produced by the SOFC into the reactor and help maintain its temperature (oscillating between $600^{\circ} \mathrm{C}$ and $800^{\circ} \mathrm{C}$ between the feeds). 
At the time of writing this paper (Sept. 2006), with a wholesale price of 0.459 Euros/l of sunflower oil, the cost of sunflower oil consumption to run the $10 \mathrm{kWel}$ USR-SOFC process would be 6.2 Euros/kWh based on fuel consumption only. This compares favourably to the average European price of 7.69 Euros per kWh.

\section{ACKNOWLEDGEMENTS}

This paper is heavily indebted to my MSc students Marc Knowles, Jonathan Powell, Mathieu Lucquiaud, Bo (Peter) Jiang and Lawrence Adediran, my Ph.D. students Elisabeth (Liz) Knight, Ian Hanley and Gavin Rickett, and Dr. Andy B. Ross. Many thanks to Dr. Martyn V. Twigg at Johnson Matthey Catalysts, Royston, UK. The work at Leeds has been funded by EPSRC grant GR/R50677 from 2002-2005, current and future work is funded by an EPSRC-Johnson Matthey CASE award (E. Knight), and EPSRC grant EP/D078199/1 until December 2009.

\section{REFERENCES}

Ben Wiens Energy Science Inc., 2006. Look at: http:/www.benwiens.com/ energy4.html\# energy 1.8.

Dunker, M., Kumar, S. and Mulawa, P.A., 2006. International Journal of Hydrogen Energy, 31 : 473-484.

Dupont, V., Ross, A.B., Hanley, I., Twigg, M.V., 2006. Accepted for publication in International Journal of Hydrogen Energy.

Ersoz, A., Olgun, H., Ozdogan, S., 2006. Journal of Power sources 154: 67-73.

Ewan, B.C.R. and Allen, R.W.K., 2005. International Journal of Hydrogen Energy 30: 809-819. Ishida, M., Zheng, D., Ahehata, T., 1987. Energy 12(2): 147-154.

Kumar, R.V., Cole, J. A., Lyon, R.K., 1999. Preprints of Symposia, J. Am. Chem. Soc. 44(4).

Lyon, R.K., Cole, J.A., 2000. Combustion and Flame 121: 249-261.

Maack, M.H. and Skulason, J.B., 2006. Journal of Cleaner Production 14: 52-64.

Marquevich, M., Sonnemann, G.W., Castells, F., Montane, D., 2002. Green Chemistry 4(5): 414423.

Marquevich, M., Coll, R., Montane, D., 2000. Industrial Engineering Chemistry Research 39: 2140-2147.

Marquevich, M., Farriol, X., Medina, F. and Montane, D., 2003. Catalysis Letters 85(1-2): 41-48.

Mazza, P., Hammerschlag, R., 2004. Institute for Lifecycle Environment assessment.

Ni, M., Leung, D.Y.C., Leung, M.K.H. and Sumathy, K., 2006. Fuel Processing Technology 87: 461-472.

Palm, T., Buch, C.B., Sauar, K.E., 1999. Green Heat and Power, Bellona Foundation, Look at: (http://www.bellona.no/imaker?id=11191\%E2\%8A\%82=1)

Powell, J., 2003. MSc thesis, MSc Environmental Pollution Control, The University of Leeds.

Rizeq, G., West, J., Frydman, A., Subia, R., Zamansky, V., Loreth, H., Stonawski, L., Wiltowski, T., Hippo, E., Lalvani, S., 2003. Quarterly Technical Progress Report (January) No. 9. DOE contract: DE-FC26-00FT40974.

Ross, A.B., Dupont, V., Hanley, I., Jones, J.M., and Twigg, M.V., 2004. Presented at: Science in Thermal and Chemical Biomass Conversion, $30^{\mathrm{th}}$ Aug-2 ${ }^{\text {nd }}$ Sept. Victoria, Canada.

Sherif, S.A., Barbir, F. and Veziroglu, T.N., 2005. The Electricity Journal 18: 62-76.

Son, S.R. and Kim, S.D., 2006. Industrial Engineering Chemistry Research 45: 2689-2696.

Tseng, P., Lee, J. and Friley, P., 2005. Energy 30: 2703-2720.

Villacampa, J.I., Royo, C., Romeo, E., Montoya, J.A., Del Angel, P. and Monzón, A., 2003. Applied Catalysis A: General 252: 363-383. 


\title{
OXIDACIÓN CATALÍTICA DEL ACEITE DE GIRASOL EN LA
} PRODUCCIÓN DEL GAS HIDRÓGENO

\author{
RESUMEN
}

En el trabajo, en breve se consideran los métodos que se utilizan en la producción de hidrógeno contemporánea para las necesidades de la industria de procesamiento del petróleo, tanto como de las futuras tecnologías que se desarrollan actualmente, como preparación de la economía global, basada en la utilización del gas hidrógeno. Luego se da el cuadro de las ventajas de la biomasa y de los biocombustibles líquidos, incluyendo los aceites de origen vegetal, como fuente de combustible en la producción sostenible del hidrógeno en forma de gas. La mayor parte del trabajo se dedica a los procesos termoquímicos en la producción del hidrógeno, que son apropiados para la transformación de aceites vegetales en el hidrógeno gaseoso. Especialmente se está considerando el trabajo que se ha hecho hasta el momento, en cuanto a la oxidación catalítica de carburo de hidrógeno mediante el vapor de agua, tanto como las ventajas y desventajas, en relación con los métodos convencionales. En continuación, está descrito el principio de un proceso de transformación de biogases totalmente nuevo, mediante el vapor de agua, llamado unmixed steam reforming' (USR), que es ajustable para todos los tipos de biogases, insensible a los problemas de índole termal, y por ello pertinente para la obtención de todos los tipos de biocombustibles gaseosos y líquidos no convencionales. Luego se presentan y discutan, sobre la base del trabajo realizado en la Universidad de Leeds, los resultados preliminares de investigación de la aplicación del proceso USR en la obtención de biocombustible del aceite de girasol. Como conclusión, se expone la descripción del futuro trabajo planificado en este campo de investigaciones.

\section{REFORMAGE À LA VAPEUR DE L'HUILE DE TOURNESOL} DANS LA PRODUCTION DE GAZ HYDROGĖNE

\author{
RÉSUMÉ
}

Cet article résume brièvement les méthodes utilisées dans la production moderne d'hydrogène pour les besoins de l'industrie de raffinement du pétrole ainsi que les technologies qui se développent actuellement dans le but d'élaborer une économie mondiale basée sur l'utilisation du gaz hydrogène. Puis, il présente les avantages de la biomasse et des carburants liquides, incluant les huiles végétales en tant que sources de carburants dans la production durable de gaz hydrogène. La plus grande partie de l'article traite des procédés thermochimiques favorables à la conversion d'huile végétale en gaz hydrogène dans la production d'hydrogène. Il traite particulièrement du travail fait jusqu'à maintenant sur le reformage catalytique des huiles végétales et des avantages et inconvénients du reformage à la vapeur traditionnel. Puis il décrit le principe d'un tout nouveau procédé de transformation de biogaz à l'aide de la vapeur d'eau appelé "unmixed steam reforming“ (USR) qui est adaptable à toutes les sortes de biogaz, insensible aux problèmes de nature thermique et ainsi propice à l'obtention de toutes les sortes de biocarburants non traditionnels sous forme de liquide ou de gaz. Puis, d'après le travail fait à l'université de Leeds, les résultats préliminaires des tests du procédé USR incluant le carburant à l'huile de tournesol sont présentés et discutés. En conclusion, il donne une description du travail projeté dans ce domaine de recherche. 
